\title{
Ecotourism Potentials of the Proposed Hallaideghe Asebot National Park, Northern Rift Valley of Ethiopia
}

\author{
Daniel Worku \\ Ethiopian Wildlife Conservation Authority, P.O. Box, 386, Addis Ababa, Ethiopia
}

In the features of deprivation of natural resources and lack of additional income, there are potentials of ecotourism in the proposed Hallaideghe-Asebot national park (HANP), which is being degraded by anthropogenic activities. This study examined ecotourism potentials of the proposed HANP for sustainable natural resources management. Descriptive research design was employed to collect relevant data. Data were collected through primary and secondary sources. The findings showed that ecotourism potentials of the study area lie in three distinctive landscapes: Hallaideghe plain, Asebot Mountain and Bilen spring areas, as well as cultural and historical attractions. Sever grazing by livestock, deforestation, and inter-ethnic conflicts are detected as the major drivers of change in the area. Finally, introducing ecotourism is important strategic direction for sustainable management of natural resources for the proposed HANP and related protected areas in Ethiopia.

Keywords: Ecotourism, HANP, Natural Resource Conservation

DOI: $10.7176 /$ JTHS/46-02

Publication date: January $31^{\text {st }} 2020$

\section{Introduction}

Tourism is a large global industry. The World Tourism Organization reported that international tourist arrivals reached 1.138 billion in 2014, 51 million more than 2013. Tourism is a system that brings together many interrelated issues such as society, nature and environment (Hari, 2010). Because of the various impacts (both positive and negative) many scholars have come to agree that mass tourism in the $21^{\text {st }}$ century is becoming unsustainable (Kelly, 2009). Because of this concern the concept of ecotourism came into being in the recent years and become popular in many developing countries.

Ecotourism is a sustainable tourism, which is based on ecological principle and sustainable development theory. Its aim is to conserve resources, especially biological diversity, and maintain sustainable use of resources, which can bring ecological experience to travelers, conserve the ecological environment and enhance economic benefits to local community (Hongshu and Mintong, 2009).

Ethiopia is experiencing an ever increasing international tourist flow. However, the development of tourism in Ethiopia is by no means commensurate with the potential of the country's multiple tourism resources (Daniel, 2011). The use that tourism can have in protected area is varied, including the conservation of natural resources, funding for infrastructure, employment opportunities, supplementary livelihood opportunities, and human development opportunities (Jennifer and Tim, 2009).

The Hallaideghe-Asebot national park is located about $280 \mathrm{~km}$ from Addis Ababa in the Ethiopian rift valley with a total area of $1098 \mathrm{~km}^{2}$ ( HANP, 2014). The relatively diverse and abundant wildlife resources which include rare and endangered species attracted the attention of Ethiopian Wildlife Conservation Authority (EWCA) to re-demarcate and upgrade the conservation status of this rich protected area; with the participation of all concerned stakeholders and new boundary is formulated from Allideghi wildlife Reserve to HANP since 2014. The newly national park is established with described boundaries and will effectively gazette when endorsed by the Council of Ministers (personal communication with Park warden, Kedir Mohammed, and redemarcation team leader, Arega Mekkonen, 2016).

From IUCN point of view the area should be a national park because:

- It has representative Savannah ecosystem

- It is one of the richest protected areas with high diversity and abundance ungulates.

- Its proximity to the capital city of Ethiopia and easy access make it suitable for tourism development.

- Having a consulted key stake holders have shown interest on the plan of making it this protected area to be a national park.

- Having indigenous and endangered tree species in the Asebot monastery.

\section{The Study Area}

Location: is found in the northern portion of the Ethiopian Great Rift-Valley, in Afar and Oromia Region, 285 $\mathrm{Km}$ north east of Addis Ababa on the way to Djibouti asphalt road. Geographically, the proposed national park is located $9^{\circ} 09^{\prime} 49^{\prime \prime}$ and $9^{0} 37^{\prime} 20^{\prime \prime}$ North and longitudes $40^{\circ} 18^{\prime} 39^{\prime \prime}$ and $40^{\circ} 38^{\prime} 01 "$ East with elevation ranges from $800 \mathrm{~m}$ around Hallaideghe plain to $2780 \mathrm{~m}$ above sea level at Asebot Mountain. 


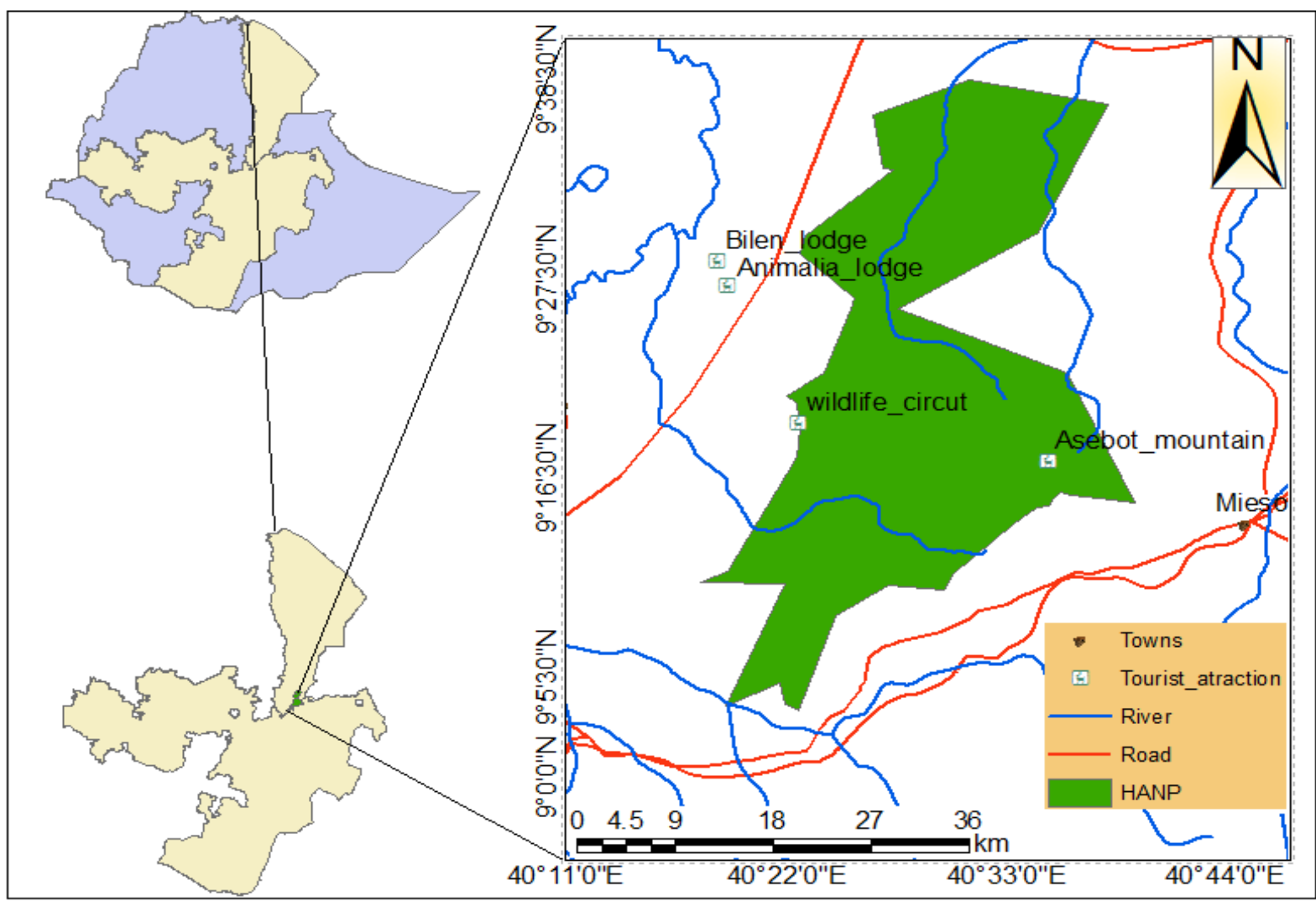

Figure 3: Location map of the study area (Source: Daniel Worku, 2016)

The park encompasses an area of $1098 \mathrm{~km}^{2}$ which comprise two distinctive landscapes: Mount Asebot and the Hallaydeghe plain. The Park is a semi-arid ecosystem with annual rain fall range between 400 and $700 \mathrm{~mm}$. The rainfall pattern is bimodal with two distinct seasons. Short rains occur during March and April while long rains occur during July and August. The temperatures range from $40 \mathrm{C}$ to $15 \mathrm{C}$. The months October to January are the coolest while the warmest temperature prevails during May and June.

Flora and Fauna: The Park features, include grassland, bare land, scatter grass and tree land (shrub land), bush land, woodland and Afro-alpine forest. The overall vegetation type that covers the largest part of the area is classified as grassland plains with savannah woodland and as the Acacia-Commiphora woodland and bush land. These vegetation types inhabit many residential and migrating birds. Additionally, mammal species like; Grevy's zebra (Flagship species), Beisa Oryx, and Soemmering's Gazelles - in the open areas, Gerenuk, and Lesser Kudus - in the bushed areas, the tiny salt Dik-Dik - under the dry acacia bushes and-Leopards, Lions, Cheetah, Black-Backed and Common Jackals, Caracal, Serval cat and Wildcats are also seen in the area very rarely.

Socio- economy: The people who settled in and around the proposed national park are the ethnic group of Afar, Oromo-Ittu and Somali-Issa. Pastorals and agro pastorals are mainly dominating the socio economic condition in HANP and the surrounding environs (Daniel Worku, 2016). Pastoral communities who dwelled in and around HANP area primarily depend on livestock for food and wealth accumulation. So this evidence shows the dynamic population increase which ultimately could put a big pressure on the natural resources unless new economic activities that can absorb this work force and endowed with means of livelihood are emerged or the existing ventures are consolidated in the area.

\section{Methods}

This study was done as part of the requirement for master degree. Both qualitative and quantitative research designs were applied for the better success of the study following (Decrop, 1999). This study used both primary and secondary sources of data. The primary data was gathered from local community, park managers, government representatives, eco-lodges owners and conservation practitioners. In addition, secondary data were used to supplement the survey data which involves the books, published and unpublished materials, government archives, reports, documents, thesis and dissertations, and internet sources. Finally, the results of the analysis were interpreted and presented using descriptive statistics. Data collected through key informant interview, focused group discussion and field observation were analyzed in the form of text to units of relevant meaning and summarization. Data collected from informal discussion were note down in field diary and afterward were analyzed by the help of text clarifications. 


\section{Result and Discussion}

Assessment on Eco-Tourism Potentials at the proposed Hallaideghe Asebot National Park (HANP) was made based on natural attractions, cultural features, and tourism activities; from the perspective of identifying conservation challenges hindering the management activity and to endorse potential lessening strategies.

\subsection{Ecotourism potentials of the proposed Hallaideghe Asebot national park}

At the proposed Hallaideghe Asebot national park, three distinctive major tourist attractions areas were identified. Namely: the Hallaideghe plain, Asebot Mountain and Bilen hot springs with the vicinities. The national park is the beginning to start the north east and east tourist spots. The extensive wilderness in this remote northeastern part of Ethiopia lies around Dallol, which has semi-desert trees and succulent scrub, semi-arid grass and plains, shrub-steppe, bush land, and acacia-wooded grassland. Witnessing the flow of lava from deep in the ground is a breathtaking sight. Its Major physical and geological features include Awash River, active volcanoes, archeological sites, extensive arid-desert ecosystem, nearby alkaline lakes and Dallol Depression. Also, the bordering areas include controlled hunting areas and national parks. The Afdem-Gewane controlled hunting area is found in the north east and the Bilen-Hertale controlled hunting area to the north. Awash National Park is found to the western side and in between these two protected areas is Gara-Gumbi open hunting area. To the east the proposed national park is the gate way to Harar wall (world heritage site), Saint Kulubi Gebreal, Table1. Major attraction sites within HANP

\begin{tabular}{|l|l|l|l|}
\hline No & Location site & Tourist attraction & GPS reading \\
\hline 1 & $\begin{array}{l}\text { Hallaideghe } \\
\text { grassland } \\
\text { plain }\end{array}$ & $\begin{array}{l}\text { Large mammals, such as Grevy's zebra, Oryx, Soemmering's gazelle, } \\
\text { gerenuk, terrestrial birds ( ostrich, kori bustard, Abyssinian ground horn } \\
\text { bill, secretary bird), acacia woodland, Extensive perennial grassland and } \\
\text { scenery }\end{array}$ & $\begin{array}{l}37 \mathrm{p} 0653587 \mathrm{E} \\
1025328 \mathrm{~N}\end{array}$ \\
\hline 2 & $\begin{array}{l}\text { Asebot } \\
\text { mountain }\end{array}$ & $\begin{array}{l}\text { Indigenous forest, monastery (moveable heritages, religious festivals), } \\
\text { highland birds, trekking, mountaineering, adventure four wheel drive, } \\
\text { tree climbers, caves, gorges, traditional life style of Oromo-Ittu people, } \\
\text { land scenery, traditional herding sites with moveable camping, } \\
\text { photography and camping }\end{array}$ & $\begin{array}{l}\text { 1027143N } \\
\text { hotheng }\end{array}$ \\
\hline 3 & $\begin{array}{l}\text { Bilen } \\
\text { spring }\end{array}$ & $\begin{array}{l}\text { Hot spring, wetland birds, lion, acacia woodland, reed grass, cliff and } \\
\text { escarpment, eco-lodge, traditional life style of the Afar people, traditional } \\
\text { herding sites with moveable camping, sunset, photography and camping }\end{array}$ & $\begin{array}{l}37 \mathrm{p} 0644872 \mathrm{E} \\
1045005 \mathrm{~N}\end{array}$ \\
\hline
\end{tabular}

Source: own survey

\subsection{Wildlife Resources of the proposed Park \\ 4.2.1. Vegetation of the Park}

The major vegetation types in and around the national park includes grassland, bush land, shrub land, wooded grassland, shrub grassland gallery/riverine forests and highland forests. About 70 plant species have been identified in the study area (Almaz, 2009). Chrysopogon plumulosus and Sporobulus iocladus comprise a relatively high percentage of herbaceous vegetation on the plains. The southern, northern, and western edges of the area are bush-grasslands or shrub lands, with Acacia senegal being the dominant species. In some parts of the grassland, P.juliflora is becoming the dominant woody species. The woody plant species in the plains of this national park include Acacia senegal, Acacia tortilis, Acacia mellifera, Balanitis aegyptiaca, Cadaba species and Grewia species. The highland forest of Mount Asebot includes Cordia africana, Croton macrostachyus, Erythrina abyssinica, Juniperus procera, Olea europaea, Podocarpus falcatus, Pouteria altissima, Rhus vulgaris (Almaz, 2009). 


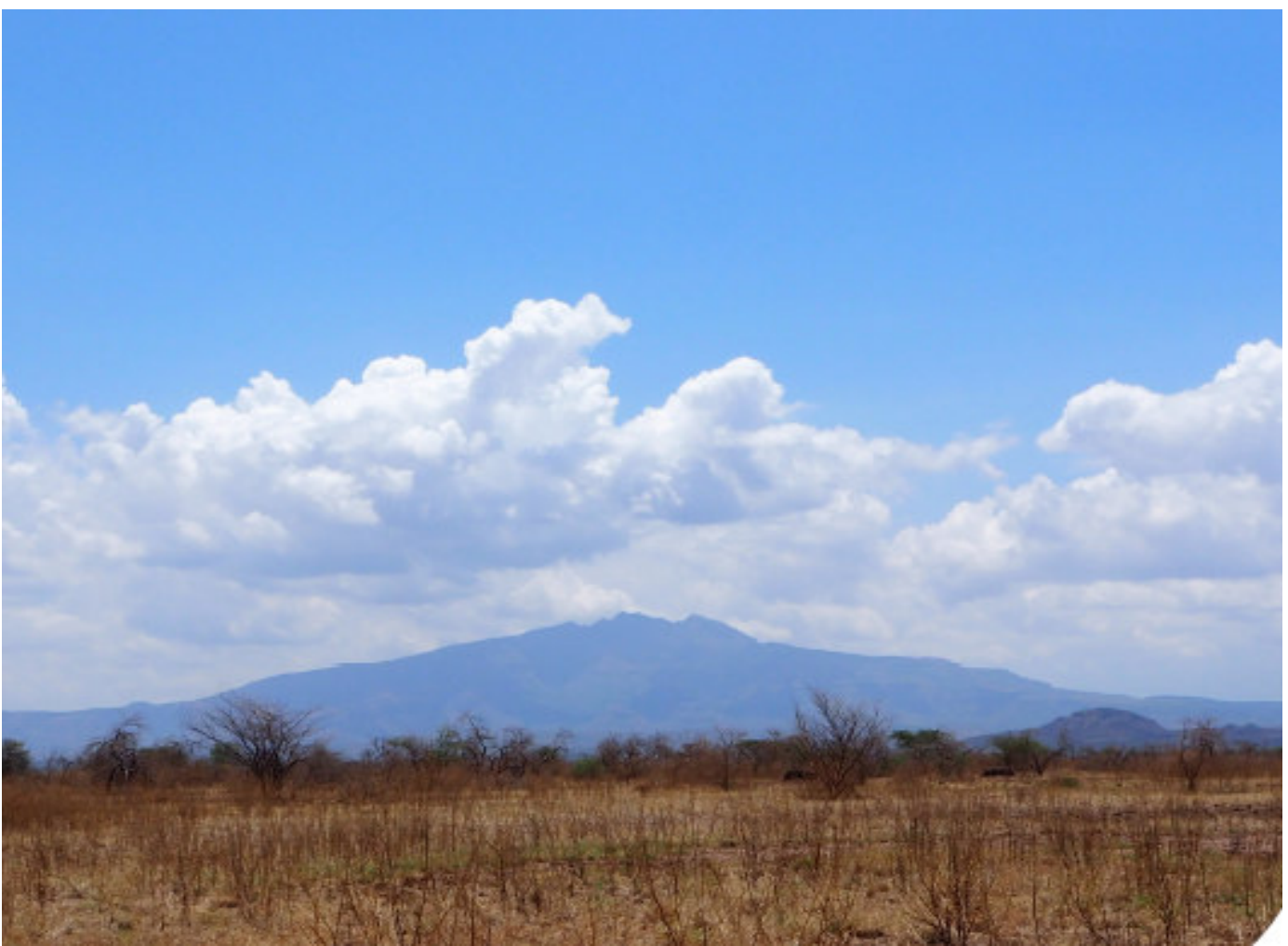

Figure 2: partial view of Hallaideghe plain with the background Mount Asebot

\subsubsection{Mammals}

The national park is primarily known for its population of Grevy's zebra (Figure 3) that thrived on the extensive perennial grass lands (Fanuel, 2012). Information obtained from the national park office indicated that More than 32 large mammal species are recorded in the park excluding bats and rats. Large mammal species include Beisa Oryx, Soemmering's Gazelle, gerenuk, lion, leopard, cheetah, black-backed Jackal, Bat-eared fox, common Jackal, spotted hyena, aardvark, tree climbers and others. According to Fanuel Kebede (2012), the Hallaideghe grass land plain harbors the largest populations of Grevy's zebra, Soemmering's Gazelle and Beisa Oryx in Ethiopia.

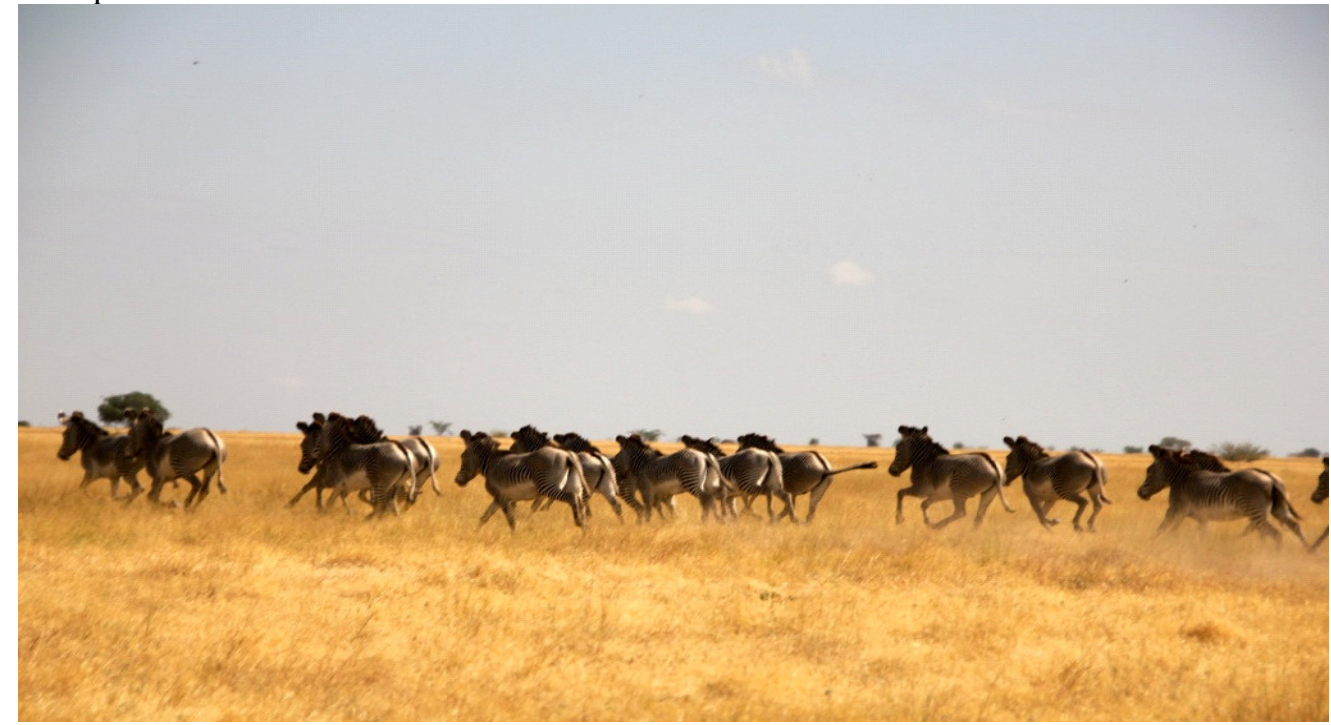

Figure 3: Grevy's Zebra (photo:HANP, 2014)

\subsubsection{Birds}

Hallaydeghe-Asebot and the surroundings count to one of the important bird areas in Ethiopia and is a resting place for migrating birds. More than 150 Bird Species have been identified. Ostriches, vultures, various species of bustards and eagles and many other birds are magnificent. The Hallaydeghe plains and the Asebot Mountain forest provide unique habitats for a diverse birdlife (Manjana Tausendfreund, 2018). Birds of prey are also common in most parts of the park and highland birds are always vocalizing in the Asebot forests (Daniel Worku, 


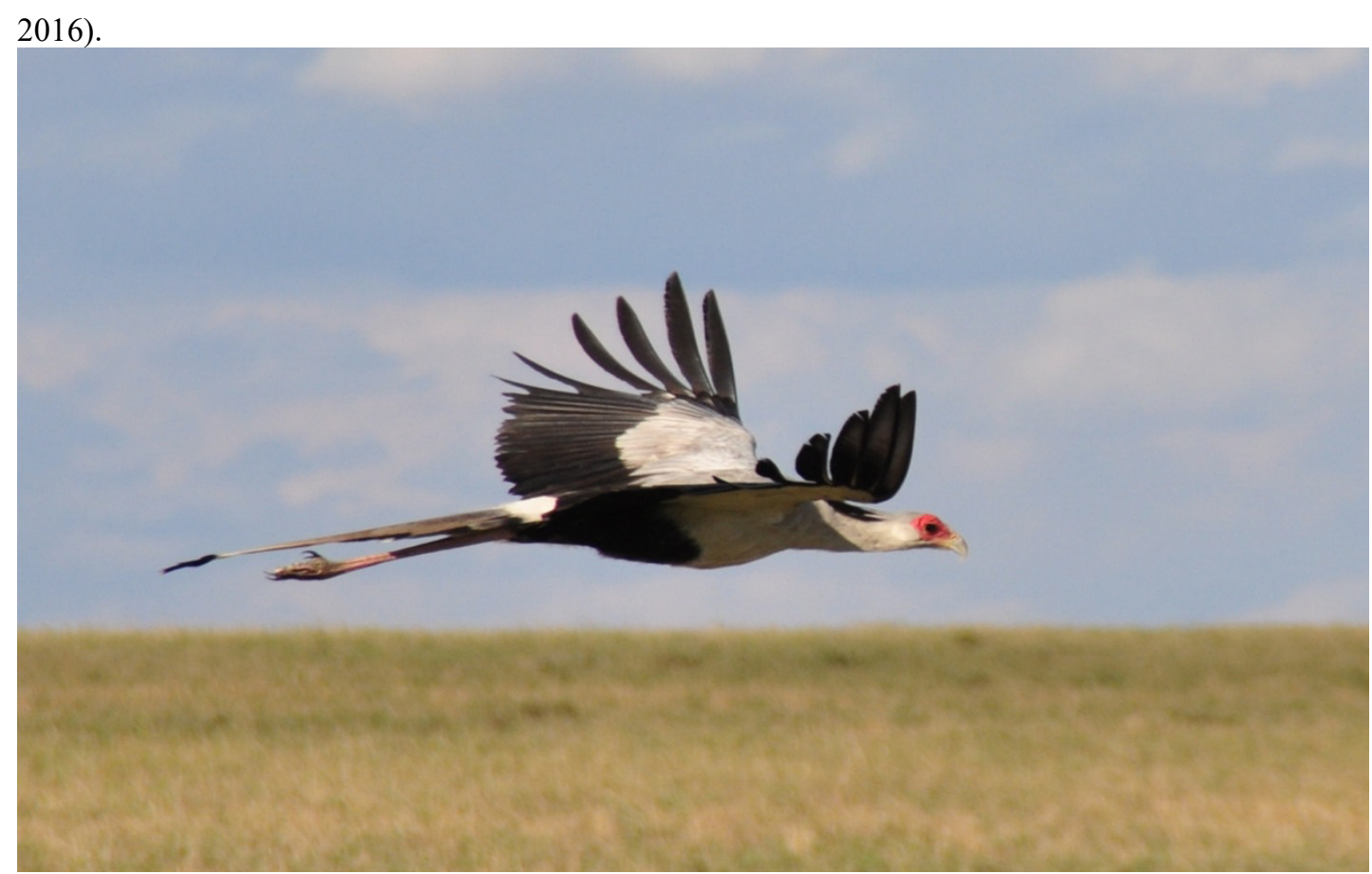

Picture 4: flying pattern of secretary bird at Hallaideghe plain

Table 2: Key bird species with national and global status within the proposed HANP

\begin{tabular}{|l|l|l|l|}
\hline No & Common name & Scientific name & Global status \\
\hline 1 & European Bee-eate & Merops apiaster & Least concern \\
\hline 2 & Arabian Bustard & Ardeotis arabs & Near threatened \\
\hline 3 & Kori Bustard & Ardeotis kori & Near threatened \\
\hline 4 & Dark Chanting-goshawk & Melierax metabates & Least concern \\
\hline 5 & Egyptian Vulture & Neophron percnopterus & Endangered \\
\hline 6 & Rüppell‘s Vulture & Gyps rueppelli & Critically endangered \\
\hline 7 & Tawny eagle & Aquila rapax & Least concern \\
\hline 8 & White-backed Vulture & Gyps africanus & Critically endangered \\
\hline 9 & White-headed Vulture & Trigonoceps occipitalis & Critically endangered \\
\hline 10 & Abyssinian Ground-hornbill & Bucorvus abyssinicus & Least concern \\
\hline 11 & Grey-headed Kingfisher & Halcyon leucocephala & Least concern \\
\hline 12 & Somali Ostrich & Struthio molybdophanes & Vulnerable \\
\hline 13 & Yellow-throated Sandgrouse & Pterocles gutturalis & Least concern \\
\hline 14 & Secretarybird & Sagittarius serpentarius & Vulnerable \\
\hline 15 & White-Faced Turaco. & Tauraco leucotis & Least concern \\
\hline 16 & Northern Red Bishop & Euplectes franciscanus & Least concern \\
\hline
\end{tabular}

Source: HANP office and field survey

\subsection{Bilen springs}

According to local informants, for thousands of years the people of Afar have had resort to the hot springs at Bilen, for water for themselves and their livestock. Also, disclosed that travelers and explorers have stopped here; camped at Bilen while following the route of the Awash River.

Key informants pointed out that there are variety of different habitats around the Bilen for birds, wildlife, flower and plants: the hot springs and surrounding wet lands, the patch of natural forest at northern tip of Elalaitu hills, acacia wood lands and savannah grass land, lakes, rocky hills, cliffs and escarpments. Mammals like warthog, dik-dik, mongoose, vervet monkey, and olive baboons are common; while frequently catch sites of lion, lesser kudu, Gerenuk and Oryx. Sunset is very outstanding reflecting on the sedge grass and best game viewing spot during the dry season. 


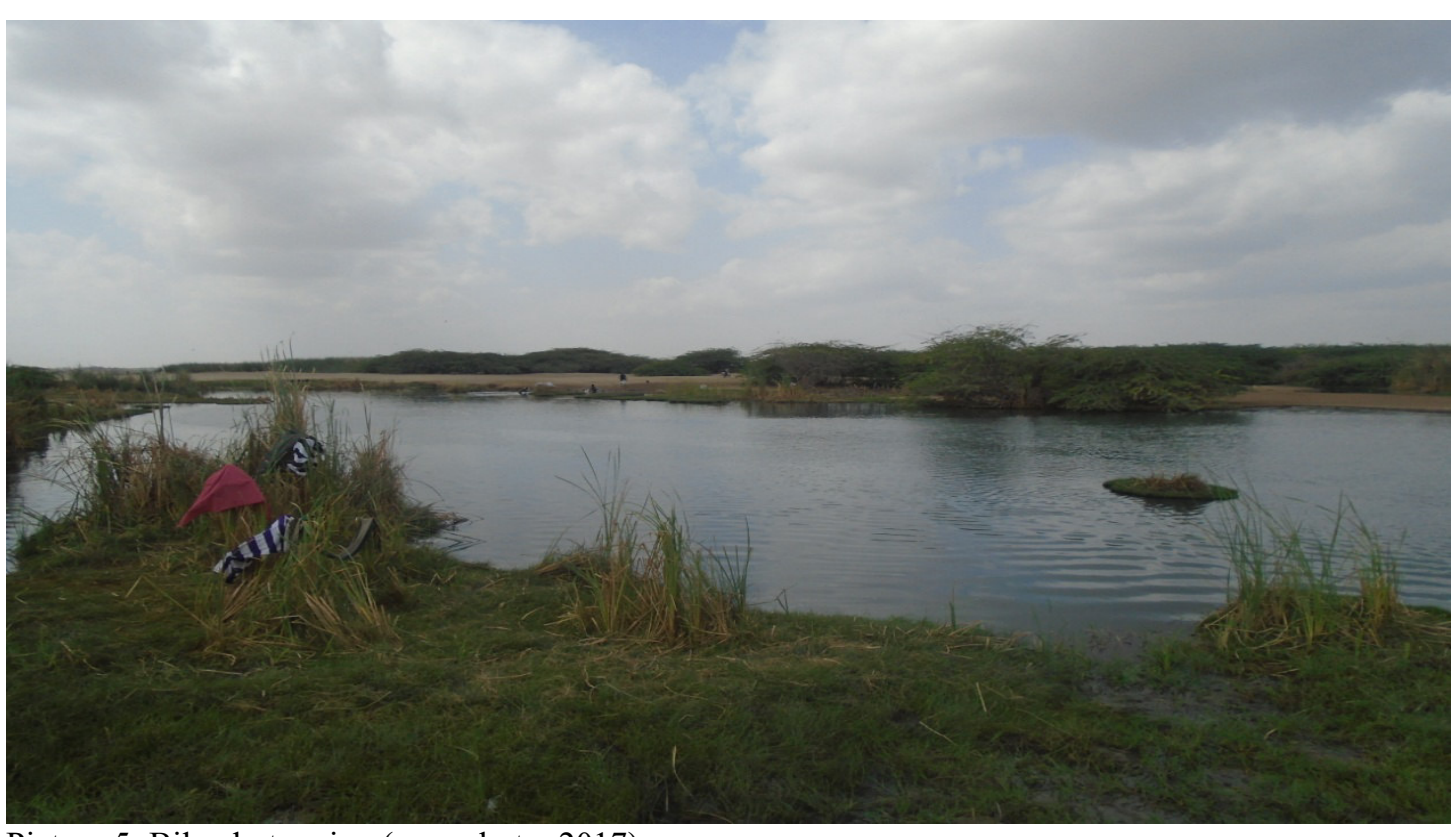

Picture 5: Bilen hot spring (own photo, 2017)

\subsection{Asebot Mountain}

Asebot Mountain with its monastery is located at coordinates of 37P 0674263E longitude and 1027143N latitude in the eastern portion of HANP and geographically positioned in west Hararege zone of Oromia Regional State, East Ethiopia. The area has significance features which constitute important attractions; Asebot was identified as having high potential for success as an ecotourism site in terms of its wilderness, remoteness, scenery, birds, wildlife, caves and monastic life (Daniel Worku, 2016).

It was established by Ethiopian Saint Father Samuel Zedebre Wegeg ${ }^{1}$ is located within western Harerghe zone of Oromia Region. Abune Samuel established this monastery in the $13^{\text {th }}$ century. The Asebot monastery has two churches: one in the middle of the mountain, named Debre Wegeg Aba Samuel, for nuns, and the other on the top of the hill, Debre Wegeg Kidist Silassie, for monks. The monasteries are education centers for disciples, the monks and the nuns also being dedicated workers involved in bee keeping, forest management and farming for their needs.

Asebot Mountain has high potential for four wheel driving, mountain climbing, adventure, and indigenous forest walking. The remaining most known old-aged endemic and indigenous trees such as Olea europea (weira), Juniperus procera (Tid), Podocarpus falcatus (Zigba), Acacia species (Girar), and Pouteria adolfifriedrici (Kerero) requires maximum protection.

\footnotetext{
${ }^{1}$ The term 'Wegeg' means a place of wisdom and light in Ge'ez language.
} 


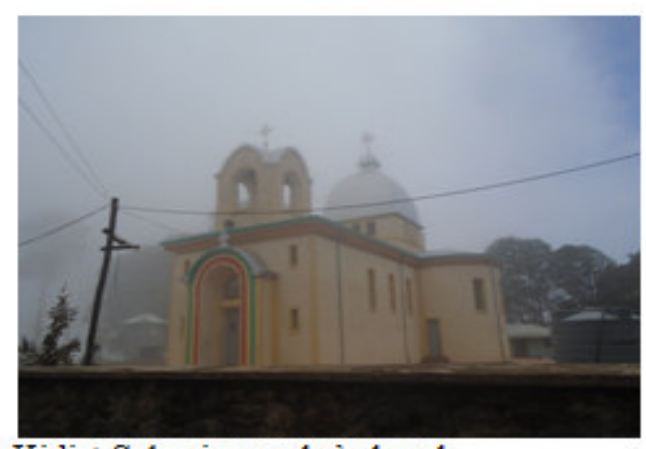

Kidist Selassie monks' church

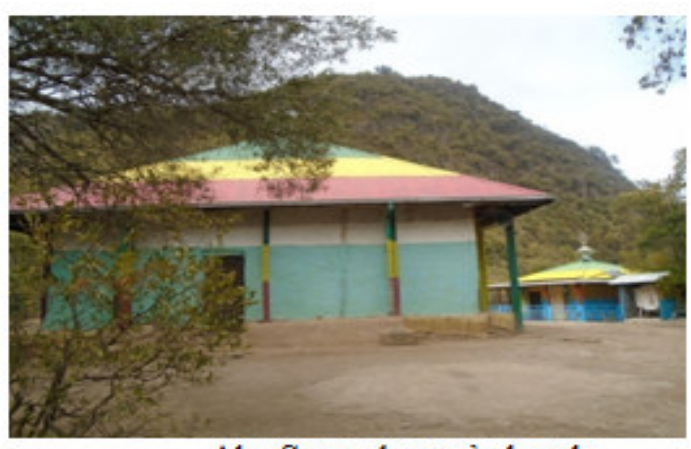

Aba Samuel nuns' church

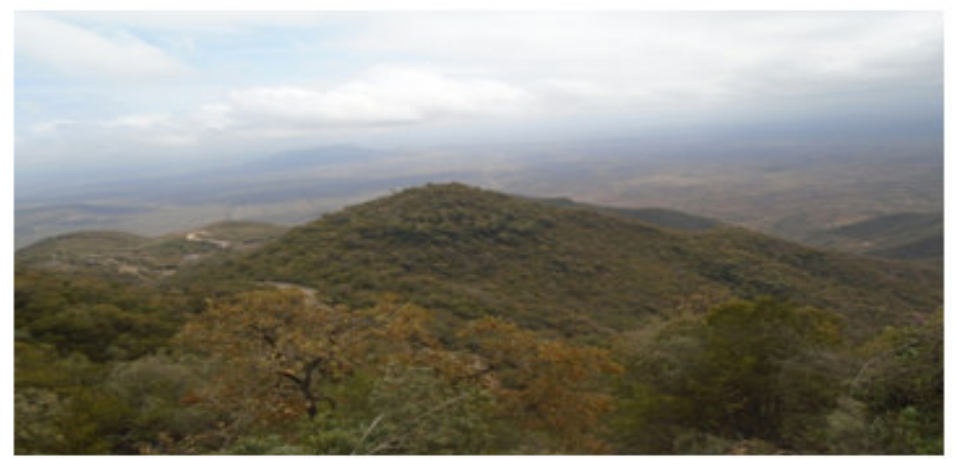

Picture 6: Churches and topography with forests at Mt. Asebot (photos: Field survey, 2016)

\subsection{Local community}

HANP and its environs demonstrated that the area is surrounded by a rich cultures that include the different ethnic groups both tangible and intangible cultural resources (mainly the Afar, Oromo, Issa-Somali people) with traditional pastoral life style and knowledge, cultural performances like dressing style, body decoration, weeding ceremonies, traditional huts, home used tools, camel riding, local handicrafts, and the monastery (church buildings, moveable heritages and events) and social gatherings like local markets, herding sites, local meeting and others; concentrates on local traditions and people as the main attractions.
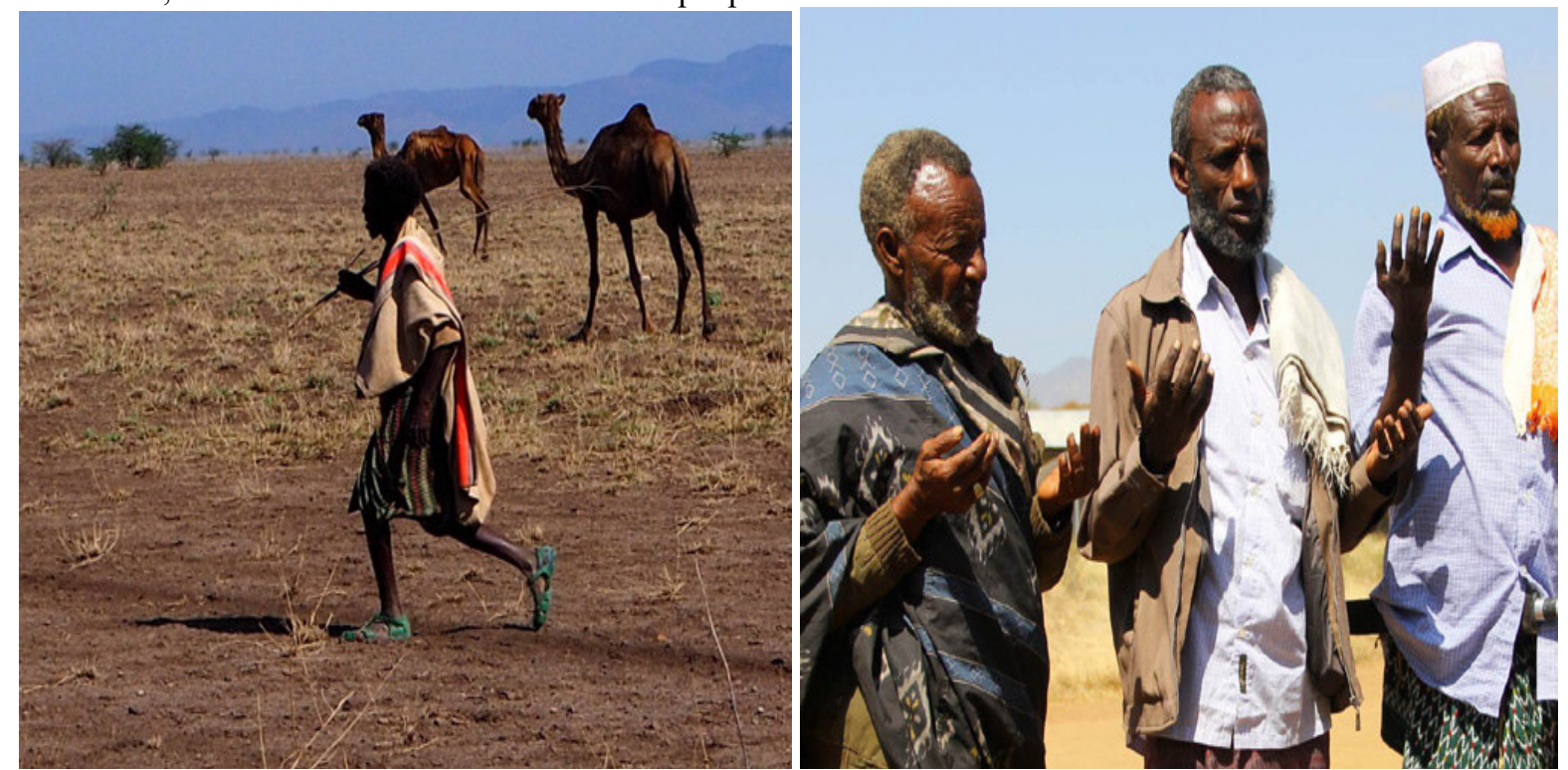

Picture 7: Local community around HANP

\subsection{Tourism Facilities}

Hallaideghe plain which is the major wildlife circuit and core area is accessible by four-wheel drive after the rainy periods. Whereas the eastern portion of the national park along the Asebot Monastery area is accessible from the main asphalt road to Debre Wegeg Kidist Silassie Church, which is $24 \mathrm{~km}$ tracks. The national park is 
surrounded by two major high ways, the Addis Ababa- Djibouti and Addis Ababa- Harar- Dire Dawa high ways, connecting the major tourist destinations of north east and east parts of Ethiopia respectively; and is easily accessible for visitors. Besides these tracks of road, the national park has buildings and three outposts to cater for visitors. Currently game rangers or park scouts are providing guiding services and accompanying tourists during visitation of the area.

There are inadequate of infrastructures, camping grounds, roads, and complementary services. Experts of the national park pointed out, many visitors who come to the area are bird watchers and rest stoppers who finished their trip at Erta Ale active volcano. So, the area is not well advertized by EWCA and other concerned stakeholders. Currently two lodges are offering service for visitors around HANP, Village Ethiopia Bilen lodge and Animalia lodge, each $10 \mathrm{~km}$ and $6 \mathrm{~km}$ far from the Head Quarter, Andido, respectively.

Around 200 tourists visit Hallaideghe-Asebot National Park annually, yielding nearly 20,000 Ethiopian Birr in year from entrance (gate) revenue, excludes guiding services and related activities. Many of these visitors are day-trippers or will overnight either camping at the Bilen hot spring or staying the nearby village Ethiopia Bilen or Animalia lodges. The recent established Doho lodge which is located $30 \mathrm{~km}$ west HANP head quarter, $18 \mathrm{~km}$ from the entrance to the Hallaideghe plain enhances tourist facilities in the destination.

\section{Conclusion and Recommendation}

Eco tourism potential of proposed Hallaideghe Asebot National Park (HANP) is assessed based on natural attractions, cultural features, and tourism facilities. The findings of the research revealed some of ecotourism potentials of HANP. The main ecotourism potentials of HANP include; flora and Fauna, extensive plain, Asebot Mountain and its monastery, Bilen springs and cultural living styles of the local community. Additionally, diverse species of mammals, birds with scenic beauty of the landscape. All the resources listed in HANP contributed to attract eco tourists or game viewers to the park. However, while currently the park offers a wealth of potential, its utilization is limited. At this point, along with the joint efforts of the local people-especially in the private sector - and the local and central government, developing and managing ecotourism in HANP are of great importance. On the other hand, anthropogenic pressures are identified as the main conservation challenges; hence the park requires immediate intervention.

\section{References}

Almaz, T. (2009). "Sustaining the Allideghi Grass Land of Ethiopia: Influences Pastoralism and Vegetation Change.” PhD Dissertation, Utah State University, and Logan, Canada.

Daniel, A. (2011). "Challenges and Opportunities for the Establishment of Community Based Ecotourism in the Awash National Park Area." Unpublished MA Thesis, Addis Ababa University, Ethiopia.

Daniel W. (2016). Assessment of Ecotourism Potentials of the proposed Hallaideghe Asebot National Park for Sustaiable Natural Resources Management, Ethiopia. Unpublished MA Thesis, Addis Ababa University

Fanuel, K. (2012). "Ecology and Community-Based Conservation of the Grevy's Zebra (Equus grevyi) and the African Wild Ass (Equus afrcanus) in the Afar Region." PhD Dissertation, Addis Ababa University, Ethiopia.

HANP (2014). Hallaideghe Asebot National park, Brochure

Hongshu, W. and Min, T. (2009). Research on Community Participation and Environmental Management of Ecotourism: North East Forestry University of China. International Journal of Business and Management, 4 (3):131-135

Jennifer, H. and Tim, G. (2009). Ecotourism and Environmental Sustainability: Principles and Practices, ASHGATE e-books.

Kelly, E. (2009). An Assessment of the Potential for Developing Ecotourism in the San Francisco Menendez Sector of El Imposible National Park, El Salvador, Alaska university press

Manjana T. (2018). Birds of Hallaideghe Asebot proposed National park, booklet 